\title{
VIRUS ISOLATION AND MOLECULAR CHARACTERIZATION OF CANINE DISTEMPER VIRUS BY RT-PCR FROM A MATURE DOG WITH MULTIFOCAL ENCEPHALOMYELITIS
}

\author{
Alexandre Mendes Amude; Glei dos Anjos Carvalho; Amauri Alcindo Alfieri*; Alice Fernandes Alfieri \\ Laboratório de Virologia Animal, Departamento de Medicina Veterinária Preventiva, Centro de Ciências Agrárias, Universidade \\ Estadual de Londrina, Londrina, PR, Brasil
}

Submitted: July 21, 2006; Approved: February 23, 2007.

\section{SHORT COMMUNICATION}

\begin{abstract}
A case of multifocal distemper encephalomyelitis in a mature dog is described. In the presented case the ante mortem clinical diagnosis of canine distemper virus (CDV) infection could not be ideally performed due to the absence of typical signs of distemper, such as myoclonus and systemic signs accompanying the nervous signs. The definitive diagnosis of distemper encephalomyelitis was only carried out at post mortem through virus isolation in cell culture from fresh central nervous system (CNS) fragments and CDV nucleoprotein gene detection in the CNS by RT-PCR.
\end{abstract}

Key words: dog, canine distemper virus, encephalomyelitis, RT-PCR

Canine distemper encephalomyelitis in immature dogs is the most common form of canine distemper virus (CDV) infection. In mature dogs, CDV may produce an unusual type of encephalomyelitis that is known as Multifocal Distemper Encephalomyelitis in Mature Dogs (MDEMD). The incidence of MDEMD is relatively low (Shell, 1990; Braund, 1994; Braund, 2001).

Although distemper is a common infectious disease in South America, in the opinion of the authors there are little scientific reports about MDEMD in Brazil. This article describes the virological results, clinical and neurological presentation, and pathological findings of a MDEMD case.

A three-year-old mixed breed non-ambulatory female dog was presented to the Veterinary Teaching Hospital with a 1week history of progressive walking difficulty related by the owner. The physical examination suggested a mild dehydratation and no abnormalities other than neurological deficits were observed. A complete neurological examination was performed. Spastic tetraparesis; cranial nerve deficits, such as spontaneous rotatory nystagmus and positional ventrolateral strabismus of the right eye, seen when the head was dorsally extended; and head ataxia, such as intentional tremor of the head, were observed. The nystagmus changed direction with different positions of the head. The neurological findings suggested that the neuroanatomical location of the lesions were in the brainstem and cerebellum.

The dog was admitted to the hospital and intravenous (IV) fluid therapy was started with a maintenance crystalloid solution (sodium chloride $0.9 \%, 50 \mathrm{ml} / \mathrm{kg} /$ day). The animal remained at the teaching hospital for six days, receiving fluid therapy and a wide spectrum antibiotic (cefalotin, $22 \mathrm{mg} / \mathrm{kg}$ IV $q$ 8h). As the dog did not recover and the neurological condition was not improving, the owner elicited euthanasia. Throughout the admission period, no evidence of respiratory, gastrointestinal, and ocular signs was observed; myoclonus was also absent.

Initial diagnostic tests included a complete blood count (CBC), cerebrospinal fluid (CSF) evaluation, and CSF culture for bacteria (5\% blood agar) and fungi (Sabouraud's dextrose agar) by routine methods. Abnormal results of the CBC included a mild lymphopenia ( 846 lymphocytes $/ \mathrm{ml}$, reference range 1000 / $\mathrm{ml}$ to 4800/l). Abnormal results on the CSF evaluation included a mild lymphocytic pleocytosis [10 white blood cells (WBC)/ml,

*Corresponding Author. Mailing address: Universidade Estadual de Londrina, Lab. de Virologia Animal, CCA/DMVP, Campus Universitário. 86051-090, Londrina, PR, Brasil. Tel.: (43) 3371-4485 - Fax: (43) 3371-4714. E-mail: alfieri@uel.br 
with $2 \%$ of neutrophils and $98 \%$ of lymphocytes; reference range 0-5 WBC/ml]. The CSF culture was negative for bacterial and fungal organisms. A second CBC was performed four days after hospital admission and severe lymphopenia (348 lymphocytes/ ml) was detected.

Body fluids (urine, serum and CSF collected ante mortem) and suspension (10\% weight/volume, in phosphate-buffered saline, $\mathrm{pH}$ 7.2) of fresh CNS fragments (brainstem and cerebellum collected at necropsy), were submitted to RT-PCR carried out as previously described (Amude et al., 2006a). The RT-PCR assay was performed as soon as the clinical samples were collected. The set of the oligonucleotides primers were designed to amplify an amplicon of $287 \mathrm{bp}$ length of the CDV nucleoprotein gene (Frisk et al., 1999). All reactions were performed using clinical samples from a dog with a neurological disease caused by Cryptococcus neoformans as negative control. CDV Rockborn strain infected MDCK (Madin Darby canine kidney) cells were used as positive control. The identities of the RTPCR products were confirmed by RFLP (restriction fragment length polymorphism) with Hinf I enzyme (Invitrogen ${ }^{\mathrm{TM}}$ Life Technologies, USA) digestion, and by nucleotide sequencing of the RT-PCR products. Brainstem and cerebellum fragments were also submitted to routine histopathological evaluation. The CDV isolation attempting, from fresh CNS fragments, was carried out by blind passages every 5 days in MDCK cell culture in roller system.

The RT-PCR results from body fluids were negative, however this technique amplified a $287 \mathrm{bp}$ size amplicon that was cleaved by Hinf I as expected to the CDV, and yielded fragments of 227 and $60 \mathrm{bp}$ size, when brainstem and cerebellum were used as clinical specimens (Fig. 1). In addition, the RT-PCR amplicons from cerebrum were purified using GFX PCR DNA and Band Purification (GE Healthcare) and sequenced in Mega BACE 1000/ Automated 96Capillary DNA Sequencer (GE Healthcare). Sequencing was performed using the anti-sense primer. The quality of the sequence obtained was analyzed with Phred/ Phrap/Consed Analyses Program (http://www.phrap.org) and the sequence identity was checked against sequences deposited in the GenBank using the BLAST software (http:// www.ncbi.nlm.nih.gov/BLAST), confirming that the $287 \mathrm{bp}$ amplicons were CDV specific.

The CDV isolation was successfully achieved in MDCK cells culture at the third passage, and it was assured by observation of CDV cytopatic effect (CPE) (Fig. 2), and through the CDV RNA detection by RT-PCR in the infected MDCK cell culture at the same passage. A negative RT-PCR in a non-inoculated control cell assured that the cell line used was CDV free.

Gross abnormalities were not observed at necropsy. Histological examinations of CNS revealed an infiltrate of perivascular mononuclear cells, mononuclear cells diffusely distributed throughout the nervous parenchyma, glial reaction, areas of malacia, and multifocal vacuoles in the white matter

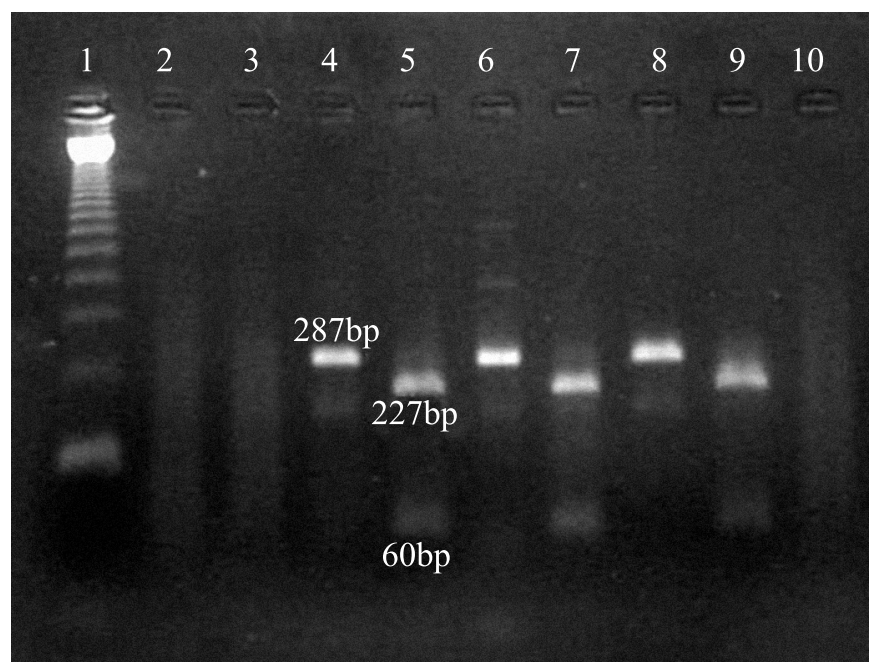

Figure 1. Agarose gel electrophoresis with ethidium bromide of RT-PCR products and yours RFLP with Hinf I restriction endonuclease. Lane 1: molecular weight marker (123bp ladder); Lane 2: negative control of the RNA extraction (utrapure sterile water); Lane 3: negative control of the reaction (brainstream of a dog with neurocriptococose); Lanes 4, 6 and 8: RT-PCR products of cerebellum (4), brainstem (6), and CDV isolated in MDCK cell culture; Lanes 5, 7 and 9: RFLP of the respectives RT-PCR products; Lane 10: RT-PCR of the MDCK cell control.

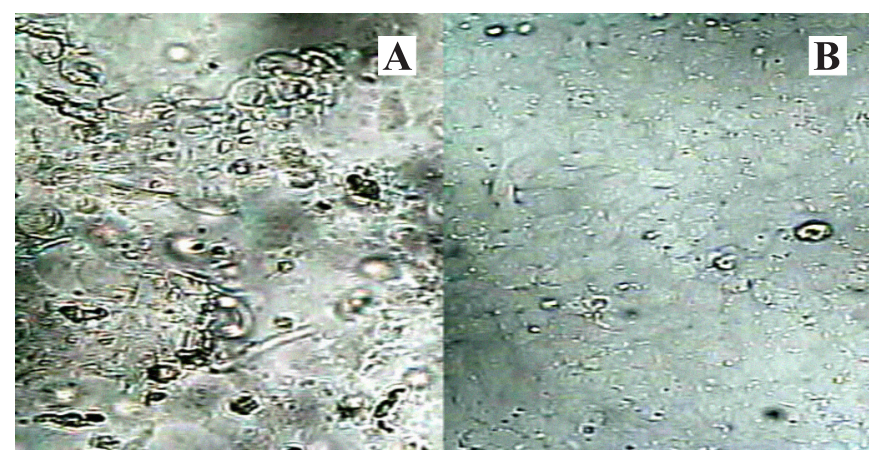

Figure 2. CDV isolated in MDCK cell culture. A) CDV cytophatic effect five days after inoculation. B) Cell control (non-infected MDCK cell culture) with the same age of infected cells.

(demyelinization), consistent of CDV chronic encephalomyelitis (Gebara et al., 2004a).

The histopathological findings, RT-PCR results, and nucleotide sequence analysis, associated with the CDV isolation in cell culture, suggest that CDV was the etiological agent of the multifocal neurological disturb in this mature dog.

Several different etiologies, such as degenerative, inflammatory, idiopathic, or infectious, may be presented with 
similar neurological signs, confusing the clinical diagnosis of nervous diseases. Systemic disturbs such as gastrointestinal and respiratory signs, and myoclonus, common and characteristic signs of CDV infection (Koutinas et al., 2002), were absent in this case. In these cases the clinical diagnosis of distemper encephalomyelitis is difficult and CDV infection may be a diagnostic challenge for the veterinarian (Tipold et al., 1992). The mild lymphocytic pleocytosis observed in CSF evaluation might suggest viral encephalomyelitis. Nevertheless this CSF finding is not specific to diagnose CDV encephalomyelitis, and may also be observed in other inflammatory CNS diseases (Chrisman, 1992; Amude et al., 2006b), such as granulomatous meningoencephalitis, and breed-specific idiopathic necrotising encephalitis.

The RT-PCR has been used in different clinical samples [organs fragments and body fluids (urine, whole blood, serum, CSF)] as a useful, fast, sensitive, and specific method to diagnose CDV infection in dogs (Frisk et al., 1999; Gebara et al., 2004b; Saito et al., 2006; Amude et al., 2006a). Unfortunately, we were unable to diagnose CDV ante mortem by RT-PCR in the presented case; since it was not possible to detect the virus in three different body fluids (urine, serum, and CSF). Technical failures were ruled out, since the reactions were performed with negative and positive controls. Besides this, the set of primers used are highly sensitive and specific (Frisk et al., 1999). Exceptionally, in cases without systemic disease, the virus may be cleared from the extra-neural tissues, by the immune responses. Some findings have suggesting that in chronic cases, due to wild-type CDV strain pathogenesis on the nervous tissues, the virus may be not detected in the extracellular space (Muller et al., 1995). These considerations could justify our RTPCR negative results on body fluids.

Although systemic signs and myoclonus are frequent with CDV infection, multifocal neurological disease in mature dogs without these typical distemper findings may be a presentation of CDV infection, such as MDEMD. In such cases, the clinical diagnosis of CDV infection may be difficult, and CDV may be not detected by RT-PCR from body fluids. For the definitive post mortem diagnosis of MDEMD, specific virological techniques, such as virus isolation in cell cultures, RT-PCR assay in CNS fragments and sequence analysis, may be necessary. CDV isolation in cell cultures is not a routine technique for the virological diagnose of distemper, however it is useful to obtain wild-type CDV strain for microbiological, molecular and antigenic studies.

\section{ACKNOWLEDGEMENTS}

The authors wish to thank the Brazilian Institutes CNPq, Fundação Araucária (FAP/PR), and CAPES for financial support. Alfieri, A.A. and Alfieri, A.F. are recipient of CNPq fellowship. We express appreciation to Dr. K.C. Médici for technical assistance.

\section{RESUMO}

\section{Isolamento e caracterização molecular do vírus da cinomose canina por RT-PCR a partir de um cão adulto com encefalomielite multifocal}

Descreve-se um caso de encefalomielite multifocal pela cinomose em um cão adulto. No caso apresentado o diagnóstico clínico da infecção pelo vírus da cinomose canina (CDV) não pode ser adequadamente realizado devido à ausência de sinais típicos da enfermidade, tais como mioclonia e sinais sistêmicos. O diagnóstico definitivo somente foi possível post mortem pelo isolamento do CDV em cultivo celular a partir dos fragmentos frescos do sistema nervoso central (SNC) e pela detecção do gene da nucleoproteína do CDV em fragmentos do SNC por meio da RT-PCR.

Palavras-chave: cão, vírus da cinomose canina, encefalomielite, RT-PCR

\section{REFERENCES}

1. Amude, A.M.; Alfieri, A.A.; Alfieri, A.F. (2006a). Antemortem Diagnosis of CDV Infection by RT-PCR in Distemper Dogs with Neurological Deficits without the Typical Clinical Presentation. Vet. Res. Commun., 30, p.679-687.

2. Amude, A.M.; Alfieri, A.A.; Balarin, M.R.S.; Faria dos Reis, A.C.; Alfieri, A.F. (2006b). Cerebrospinal fluid from a 7-month-old dog with seizure-like episodes. Vet. Clin. Pathol., 35, 119-122.

3. Braund, K.G. (1994). Clinical Syndromes in Veterinary Neurology, 2nd ed. Mosby, St Louis, 477 p.

4. Braund, K.G. (2001). Inflammatory Diseases of the Central Nervous System. http://www.ivis.org. Accessed 11 November 2001.

5. Chrisman, C.L. (1992). Cerebrospinal Fluid Analysis. Vet Clin North Am: Small Anim Pract., 22, 781-807.

6. Frisk, A.L.; Konig, M.; Moritz, A.; Baumgärtner, W. (1999). Detection of canine distemper virus nucleoprotein RNA by reverse transcription-PCR using serum, whole blood, and cerebrospinal fluid from dogs with distemper. J. Clin. Microbiol., 37, 3634-3643.

7. Gebara, C.M.S.; Wosiacki, S.R.; Negrão, F.J.; Alfieri, A.A.; Alfieri A.F. (2004a). Lesões histopatológicas no sistema nervoso central de cães com encefalite e diagnóstico molecular da infecção pelo vírus da cinomose canina. Arq. Bras. Med. Vet. Zootec., 56, 168-174.

8. Gebara, C.M.S.; Wosiacki, S.R.; Negrão, F.J.; de Oliveira, D.B.; Beloni, S.N.E.; Alfieri, A.A.; Alfieri A.F. (2004b). Detecção do gene da nucleoproteína do vírus da cinomose canina por RT-PCR em urina de cães com sinais clínicos de cinomose. Arq. Bras. Med. Vet. Zootec., 56, 480-487.

9. Muller, C.F.; Fatzer, R.S.; Beck, K.; Vandevelde, M.; Zurbriggen, A. (1995). Studies on canine distemper virus persistence in the central nervous system. Acta Neuropathol., 89, 438-445.

10. Saito, T.B.; Alfieri, A.A.; Wosiacki, S.R.; Negrão, F.J.; Morais, H.S.A.; Alfieri, A.F. (2006). Detection of canine distemper virus by reverse transcription-polimerase chain reaction in the urine of dogs with clinical signs of distemper encephalitis. Res. Vet. Sci. 80, 116-119.

11. Shell, L.G. (1990). Canine Distemper. Compend. Contin. Educ. Pract. Vet., 12, 173-179.

12. Tipold, A.; Vandevelde, M.; Jaggy, A. (1992). Neurological manifestation of canine distemper virus infection. J. Small. Anim. Pract., 33, 466-470. 